\title{
Hygienic-sanitary quality and antimicrobial sensitivity profile of Escherichia coli in milk and cheese sold illegally in municipalities of northern Mato Grosso, Brazil ${ }^{*}$
}

\author{
Renata Henriques Ragi Pena' (1) https://orcid.org/0000-0003-0284-2888 \\ Filipe Freitas ${ }^{1}$ (D) https://orcid.org/0000-0003-3747-1562

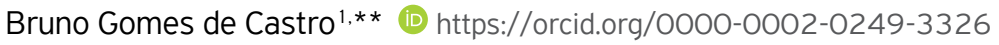 \\ 1. Universidade Federal de Mato Grosso - Campus Universitário de Sinop - Laboratório de Diagnóstico em Sanidade Animal - \\ Sinop (MT), Brazil. \\ * This paper is part of the dissertation thesis of the first author. \\ ** Corresponding author: castrobg@gmail.com
}

\begin{abstract}
Products such as milk and cheese produced by hand and sold by small producers in open markets and at home are a reality in Brazil, despite legal prohibitions. In many cases, this leads to the production of food without hygienic conditions, which may constitute an important source of transmission of foodborne diseases and a danger to public health. This study proposes to examine the hygienicsanitary quality of milk and cheese sold illegally in municipalities of northern Mato Grosso, Brazil, to undertake a phenotypical investigation of the presence of resistance of isolated colonies to antimicrobials and to detect the production of $\beta$-lactamase enzymes: extendedspectrum $\beta$-lactamase (ESBL), AmpC $\beta$-lactamases (AmpC) and carbapenemases. The 25 milk and 37 cheese samples analyzed were subjected to the most probable number (MPN) test, isolation on eosin-methylene blue agar (EMB) agar and Escherichia coli identification by biochemical tests and disk diffusion test. Results showed that $76 \%$ of the milk samples and $67.57 \%$ of the cheese samples had thermotolerant coliform counts above the value allowed by the legislation. The milk and cheese isolates showed 15.79 and $5.88 \%$ resistance, respectively, to at least one of the tested antimicrobials. No $\beta$-lactamase enzyme production was observed in the isolates.
\end{abstract}

Keywords: foodborne diseases; MPN; phenotypic tests; $\beta$-lactamases.

\section{INTRODUCTION}

According to the World Health Organization, foodborne diseases affect one in ten inhabitants every year in the world and, from farm to table, the food can be contaminated in many ways (WHO, 2017b). The increasing consumption of food in public places and the consumption of organic and artisanal foods are a current trend and if good manufacturing practices (GMP) are not complied with throughout the production chain, products can become a danger to consumers (WHO, 2016).

Artisanal milk and cheese produced by small farmers are a reality in Brazil, where these products are sold in open markets and at home, despite prohibitions by the national legislation (BRAZIL, 2017) and evidence of low hygienic-sanitary quality and high rates of Escherichia coli in them (WHO, 2018b).

Escherichia coli is considered an indicator microorganism (FORSYTHE, 2013) and its presence in the food provides information on contaminations of fecal origin, the probable presence of pathogens and spoilage microorganisms, as well as the sanitary conditions that the product undergoes during its production (SILVA et al., 2010). It is also considered a sensor in the examination of resistance because it is the most widely studied agent, in addition to having a diversified ecology and various resistance mechanisms (VILA et al., 2016).

Therefore, this study proposes to investigate the hygienic-sanitary quality of raw milk and its by-products sold illegally in the northern region of Mato Grosso, Brazil, as well as to determine the antimicrobial sensitivity profile of E. coli isolated from the samples and detect multidrug resistance and production of $\beta$-lactamases enzymes in order to highlight the impact that the consumption of these products can have on the health of consumers, due to the possibility of pathogenic and/or resistant microorganism dissemination. 


\section{METHODS}

The study involved 25 raw milk and 37 cheese samples acquired directly from farmers in open markets and at home in 11 municipalities in the northern region of Mato Grosso.

Hygienic-sanitary quality was evaluated by the most probable number (MPN) test, following the American Public Health Association (APHA), as recommended by SILVA et al. (2010). From one of the positive tubes of the EC broth used in the thermotolerant-coliform investigation, culture was performed on eosin-methylene blue agar (EMB). After incubation at $35^{\circ} \mathrm{C}$ for $18-24 \mathrm{~h}$, five typical colonies (black colonies with or without greenish metallic luster around them) were collected individually and inoculated in tubes containing brain heart infusion broth (BHI), in which biochemical tests were subsequently performed following the methodology proposed by RIBEIRO (2011).

Phenotypic detection of antimicrobial resistance was carried out using disk diffusion test as recommended by the Clinical and Laboratory Standards Institute (CLSI, 2017). After the inhibition halos were read, the strains were classified as sensitive, intermediate or resistant to the antimicrobials (CLSI, 2017; 2018).

The antimicrobial disks used were selected according to CLSI $(2017 ; 2018)$ guidelines and also based on the study of SANTIAGO (2013). These consisted of amoxicillin + clavulanic acid $30 \mu \mathrm{g}$, ampicillin $10 \mu \mathrm{g}$, amoxicillin $10 \mu \mathrm{g}$, penicillin $10 \mathrm{IU}$, oxacillin $1 \mu \mathrm{g}$, cefepime $30 \mu \mathrm{g}$, ceftriaxone $30 \mu \mathrm{g}$, cefoxitin $30 \mu \mathrm{g}$, ceftazidime $30 \mu \mathrm{g}$, cefalotin $30 \mu \mathrm{g}$, aztreonam $30 \mu \mathrm{g}$, imipenem $10 \mu \mathrm{g}$, gentamicin $10 \mu \mathrm{g}$, neomycin $30 \mu \mathrm{g}$, ciprofloxacin $5 \mu \mathrm{g}$ and sulfamethoxazole + trimethoprim $25 \mu \mathrm{g}$.

Results were also examined for the determination of multidrug resistance to antimicrobials. Strains that showed resistance to at least one agent in three or more distinct categories of antimicrobials were considered multidrug-resistant (RIBEIRO et al., 2016) and were subsequently subjected to the $(\mathrm{a} / \mathrm{b}) \times 100$ formula to determine their percentage, where a corresponds to the number of antimicrobials to which the isolate was resistant and $b$ to the number of antimicrobials to which the isolate was exposed (BARRETO et al., 2012).

To detect the extended-spectrum $\beta$-lactamase enzyme (ESBL), isolates that showed resistance to a third-generation cephalosporin (ceftazidime or ceftriaxone) and sensitivity to clavulanic acid were suspected of producing the enzyme classified as ESBL (2be). To confirm the production of this enzyme, the disk approximation test, the minimum inhibitory concentration (MIC) test (using the Etest strip) and the three-dimensional extract (TET) test were carried out as described by SANTIAGO (2013).

For the detection of the AmpC enzyme, isolates that showed resistance to cefoxitin were suspected of producing AmpC-type enzymes. To confirm, the TET test was carried out, as described by SANTIAGO (2013).

To detect the carbapenemase enzyme, isolated colonies resistant to imipenem were subjected to disk diffusion test, using the ertapenem disk (SANTIAGO, 2013). Suspected isolates were also subjected to the modified Hodge test, according to CLSI guidelines (CLSI, 2017).

\section{RESULTS AND DISCUSSION}

The minimum and maximum reference values allowed by Brazilian legislation, the corresponding regulations, the number of colonies characteristic of $E$. coli isolated from the samples and the results obtained in the MPN tests performed on the raw milk samples that participated in this study to measure the hygienic-sanitary quality of the analyzed products are specified in Table 1.

Table 1. Results of MPN test of raw milk samples.

\begin{tabular}{lcccc}
\hline N of samples & Sample & $\begin{array}{c}\text { Total coliforms } \\
\text { (MPN/mL) } \\
\text { above standards }\end{array}$ & $\begin{array}{c}\text { Thermotolerant } \\
\text { coliforms (MPN/mL) } \\
\text { above standards }\end{array}$ & $\begin{array}{c}\text { Isolated } E \text {. coli } \\
\text { colonies }\end{array}$ \\
\hline $\mathbf{2 5}$ & Raw milk & $96 \%(24 / 25)$ & $76 \%(19 / 25)$ & $60,80 \%(76 / 125)$ \\
\hline Reference values & & $\mathrm{m}=2 \mathrm{M}=4 \mathrm{MPN} / \mathrm{mL}$ & $\mathrm{m}=2 \mathrm{M}=4 \mathrm{MPN} / \mathrm{mL}$ & - \\
\hline Reference & & $\mathrm{N}$ No. $62 / 2011$ & $\mathrm{RDC} 12 / 2001$ & - \\
\hline
\end{tabular}

Source: research data. $\mathrm{M}$ - maximum allowed value; $\mathrm{m}$ - minimum allowed value; $\mathrm{NI}$ - Normative Instruction; RDC - Collegiate Board Resolution (Resolução da Diretoria Colegiada). 
Acceptable values for both total (TC) and thermotolerant coliforms (TTC) for milk intended for consumption are at least two and at most four coliforms at 35 or $45^{\circ} \mathrm{C} / \mathrm{mL}$ (BRAZIL, 2001; 2011). Of the 25 milk samples analyzed, $96 \%$ (24/25) were above the limits required by legislation for TC and 76\% (19/25) were above the acceptable limits for TTC. Of these 25 samples, 125 colonies were initially isolated and 60.8\% (76/125) were classified as E. coli after confirmation with biochemical tests.

Based on the information contained in the Collegiate Board Resolution (CBR, Resolução da Diretoria Colegiada) No. 12 of 2001, the 37 cheese samples analyzed were classified into cheese of medium moisture $(36 \%<$ moisture $<46 \%)$ and very high moisture (moisture $=55 \%)($ BRAZIL, 2001).

The results obtained in the MPN tests for the cheese samples of medium and very high moisture, as well as the reference values and their corresponding regulations, are shown in Tables 2 and 3, respectively.

Table 2. Results of MPN test of medium-moisture cheese samples.

\begin{tabular}{lcccc}
\hline N of samples & Sample & $\begin{array}{c}\text { Total coliforms } \\
(\mathrm{MPN} / \mathrm{mL}) \\
\text { above standards }\end{array}$ & $\begin{array}{c}\text { Thermotolerant } \\
\text { coliforms (MPN/mL) } \\
\text { above standards }\end{array}$ & $\begin{array}{c}\text { Isolated } E \text {. coli } \\
\text { colonies }\end{array}$ \\
\hline 02 & $\begin{array}{c}\text { Medium-moisture } \\
\text { cheese }\end{array}$ & $\mathrm{O} \%(\mathrm{O} / 2)$ & $0 \%(0 / 2)$ & $100 \%(10 / 10)$ \\
\hline Reference values & & $\mathrm{m}=1,000 \mathrm{M}=5,000 \mathrm{MPN} / \mathrm{g}$ & $\mathrm{m}=500 \mathrm{M}=1,000 \mathrm{MPN} / \mathrm{g}$ & - \\
\hline Reference & & Ord. No. $146 / 1996$ & $\mathrm{RDC} 12 / 2001$ & - \\
\hline
\end{tabular}

Source: research data. M - maximum allowed value; $\mathrm{m}$ - minimum allowed value; Ord. - ordinance; RDC - Collegiate Board Resolution (Resolução da Diretoria Colegiada).

Table 3. Results of the MPN test of very high moisture cheese samples.

\begin{tabular}{lcccc}
\hline N of samples & Sample & $\begin{array}{c}\text { Total coliforms } \\
\text { (MPN/mL) } \\
\text { above standards }\end{array}$ & $\begin{array}{c}\text { Thermotolerant } \\
\text { coliforms (MPN/mL) } \\
\text { above standards }\end{array}$ & $\begin{array}{c}\text { Isolated } E \text {. coli } \\
\text { colonies }\end{array}$ \\
\hline 35 & $\begin{array}{c}\text { Very high } \\
\text { moisture cheese }\end{array}$ & $100 \%(35 / 35)$ & $71.43 \%(25 / 35)$ & $71.71 \%$ \\
Reference values & & $\mathrm{m}=10 \mathrm{M}=1,000 \mathrm{MPN} / \mathrm{g}$ & $\mathrm{m}=50 \mathrm{M}=500 \mathrm{MPN} / \mathrm{g}$ & - \\
\hline Reference & & Ord. No. $146 / 1996$ & RDC $12 / 2001$ & - \\
\hline
\end{tabular}

Source: research data. M - maximum allowed value; m - minimum allowed value; Ord. - ordinance; RDC - Collegiate Board Resolution (Resolução da Diretoria Colegiada).

Among the medium-moisture cheeses, represented in this study by the mozzarella cheeses, the minimum and maximum values allowed in the legislation range from 500 to 1,000 coliforms at $45^{\circ} \mathrm{C} / \mathrm{g}$ for TTC (BRAZIL, 2001) and from 1,000 to 5,000 coliforms at $35^{\circ} \mathrm{C} / \mathrm{g}$ for TC (BRAZIL, 1996). The two samples classified in this category were within the standards required by the legislation for both TC and TTC. From these two samples, 10 colonies were initially isolated (five from each sample) and, after biochemical tests, $100 \%$ (10/10) were classified as E. coli.

As for the cheese samples classified in the category of very high moisture, represented in this study by "minas frescal" cheese, the tolerable threshold values range from a minimum of 10 to a maximum of 1,000 coliforms at $35^{\circ} \mathrm{C} / \mathrm{g}$ for TC (BRAZIL, 1996) and from 50 to 500 coliforms at $45^{\circ} \mathrm{C} / \mathrm{g}$ for TTC (BRAZIL, 2001). Of the total 35 very high moisture cheese samples, $100 \%$ (35/35) were above the acceptable limits for TC and 71.43\% (25/35) were above the limits required by legislation for TTC. Of the 35 samples, 175 colonies were initially isolated, $71.71 \%$ (136/175) of which were classified as $E$. coli after biochemical tests.

There are four ways in which milk can be contaminated with pathogenic microorganisms: by fecal contamination during or after milking; through contaminated humans; by direct passage of blood into milk from systemic infection; or through mastitis (LUCEY, 2015). It is due to these factors that, among other specifications, decree No. 9013 of 2017 determines that milk destined for the direct consumption of the population and/or used for the production of cheeses must undergo a previous adequate heat treatment process to ensure product safety. An exception is granted in the case of cheeses that ripen at a temperature above $5{ }^{\circ} \mathrm{C}$ for at least 60 days, for which the heat treatment is not mandatory (BRAZIL, 2017).

Cross contamination plays an important role in food contamination and occurs when food is contaminated directly or indirectly by pathogenic microorganisms. There are several stages at which this contamination can occur and, from 
the field to the table, there are several possibilities of the food becoming contaminated. If good agricultural practices and good manufacturing, storage, transport and distribution practices are not adopted in their production, they can become a danger to consumers (WHO, 2016; 2017b).

Among other specifications, decree No. 9013 of 2017 determines that milk intended for direct consumption by the population and milk used for the production of cheese must originate from healthy animals and undergo an appropriate heat treatment process to ensure the safety of the products, since pasteurization eliminates pathogenic microorganisms (BRAZIL, 2017). However, the quality of a product cannot be recovered with the process, given that even after pasteurization, milk retains a viable microbial population of around 0.1 to $0.5 \%$ of the initial count (LUZ et al., 2011). Therefore, it is essential that milk - whether for direct consumption or used in the manufacture of by-products - have good microbiological quality, observing all production, storage, transport and distribution requirements.

The raw milk samples analyzed in this study mostly reused 1 or $2 \mathrm{~L}$ polyethylene terephthalate (PET) bottles or $1 \mathrm{~L}$ plastic bag packages similar to those used for pasteurized milk, which were tied at one end. The cheeses, however, were packed in transparent plastic bags tied at the end and some were also laid on Styrofoam trays.

In terms of packaging, decree No. 9013 of 2017 determines that it must ensure protection according to their characteristics, as well as storage and transport conditions and that it must be intact and properly sanitized following the criteria established by the Federal Inspection Service (Serviço de Inspeção Federal, SIF). In the specific case of milk, automatic filling must be done in a closed circuit and the equipment responsible for this process must contain devices that ensure the antiseptic conditions of the packaging. Packaging for the products must also be authorized by health regulatory agencies (BRAZIL, 2017).

With respect to the antimicrobial resistance of the isolated samples of the 212 colonies characteristic of $E$. coli in the samples analyzed in this study, 76 belonged to milk and 136 to cheese. The results obtained for the antimicrobial susceptibility test in raw milk and cheese, as well as the antimicrobials used, are shown in Figures 1 and 2, respectively.

According to the results of the susceptibility tests carried out on the 76 colonies characteristic of $E$. coli isolated from raw milk samples (Fig. 1), 84.21\% (64/76) of them exhibited sensitivity to all tested antimicrobials. Despite the high levels of sensitivity, resistance was observed in approximately $15.79 \%$ (12/76), whereas $13.16 \%$ (10/76) showed intermediate sensitivity to at least one of the antimicrobials used in this study.

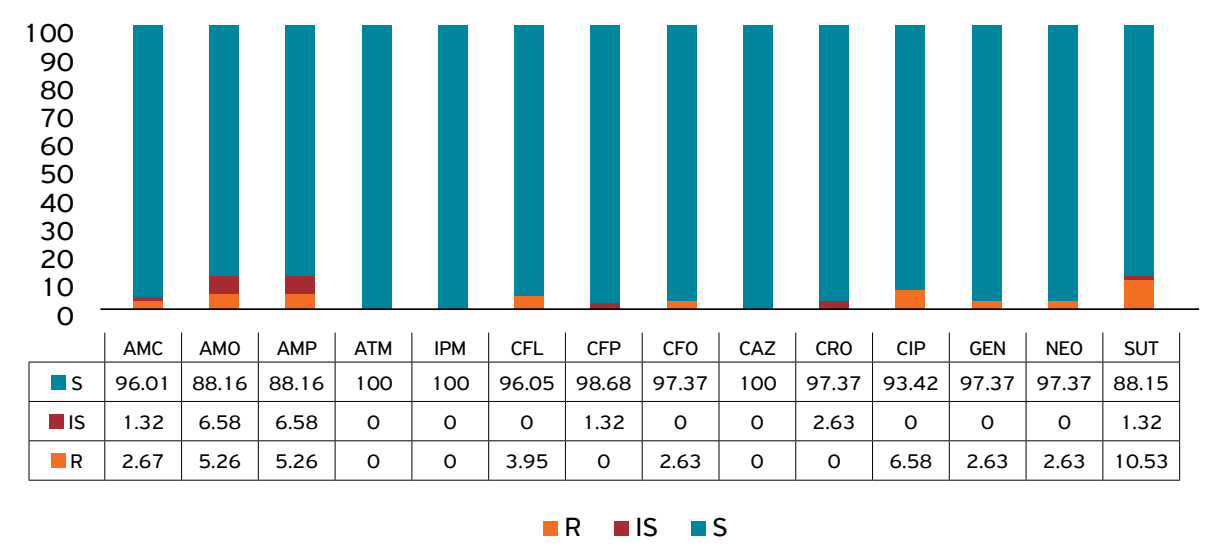

Figure 1. Results of antimicrobial susceptibility tests in Escherichia coli colonies isolated from samples of raw milk sold illegally in municipalities in the northern region of Mato Grosso, Brazil.

Source: research data. AMC - amoxicillin + clavulanic acid, AMO - amoxicillin, AMP - ampicillin, ATM - aztreonam, IPM - imipenem, CFL - cefalotin, CFO - cefoxitin, CAZ - ceftazidime, CRO - ceftriaxone, CFP - cefepime, CIP - ciprofloxacin, NEO - neomycin, SUT - sulfamethoxazole + trimethoprim. R - resistance, IS - intermediate sensitivity, S - sensitivity.

Of the 136 colonies isolated from the cheese samples, $94.12 \%$ (128/136) showed sensitivity to all tested antimicrobials. However, in $5.88 \%$ of the isolated strains, resistance and intermediate sensitivity to at least one of the tested drugs were observed (Fig. 2).

Despite occurring naturally, misuse, indiscriminate sale and prescription without criteria in some countries contribute to the increase and appearance of new resistance mechanisms in bacteria (WHO, 2018a). For this reason, entities such as the World Health Organization (WHO), the World Organization for Animal Health (OIE) and the United Nations Food and Agriculture Organization (FAO) have attempted to combat the global threat of resistance to antimicrobials (OIE, 2018) by promoting actions such as enhancing antimicrobials of medical importance in animals to safeguard the effectiveness 
of antimicrobials of importance to human health (WHO, 2017a) and implementing an international standard to increase awareness and knowledge, as well as training professionals working in the production area (OIE, 2018). In this way, space is created for the One Health concept to prevent and control emergency diseases that stem from the interrelationship between animals, humans and ecosystems (OIE, 2019).

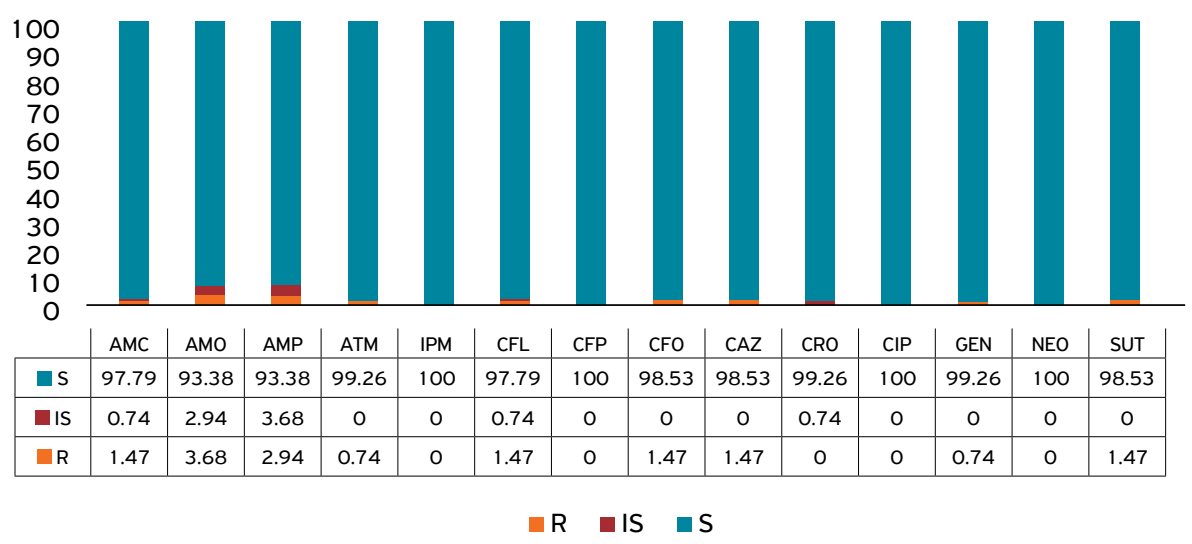

Figure 2. Results of antimicrobial susceptibility tests in Escherichia coli colonies isolated from samples of cheese sold illegally in municipalities in the northern region of Mato Grosso, Brazil.

Source: research data. AMC - amoxicillin + clavulanic acid, AMO - amoxicillin, AMP - ampicillin, ATM - aztreonam, IPM- imipenem, CFL-cefalotin, CFO - cefoxitin, CAZ- ceftazidime, CRO - ceftriaxone, CFP-cefepime, CIP-ciprofloxacin, NEO - neomycin, SUT - sulfamethoxazole + trimethoprim. R - resistance, IS - intermediate sensitivity, S - sensitivity.

Transmission of resistant microorganisms by animals can occur directly (humans or animals) or indirectly (via the food chain or the environment) and because many of them cause disease in humans, control over the spread of resistant agents is extremely important for global public health (WHO, 2017a).

Normative Instruction No. 62 of 2011 determines that food-processing companies must register their suppliers with the Brazilian Ministry of Agriculture, Livestock and Supply and implement a raw material quality program associated with a continuing education program whose effectiveness must be proven through product quality analysis (BRAZIL, 2011). On this basis, the obligation to control the quality of the raw material most likely causes producers who deliver their products to processing companies to endeavor in order to achieve greater control over mastitis and one form of controlling it is through antibiotic therapy.

This fact can be corroborated by an epidemiological survey and bacteriological study carried out on dairy farms in the southern region of the state of Rio de Janeiro, which proved that $80 \%$ of the surveyed farms had unsatisfactory hygienic conditions in the milking line and regarding the water supply. For these reasons, the treatment of mastitis was excessively dependent on the use of antimicrobials (ALENCAR et al., 2014).

As can be seen in the present study, the vast majority of raw milk and cheese samples showed low hygienic-sanitary quality and the colonies isolated from these samples exhibited high levels of sensitivity to the tested antimicrobials. This suggests that these strains most likely come from commensal and/or environmental strains and, consequently, the microorganisms did not suffer selective pressure due to the non-use of antimicrobials. In domestic environments and in subsistence agriculture, antimicrobials are used mainly for the treatment of the animal rather than for the promotion of growth or as a prophylactic measure. Thus, the incidence of antimicrobial resistance is low (ROUSHAM et al., 2018).

Lack of good milking and hygiene practices during the production process on the part of employees will result in a contamination cycle that will originate contaminated products, constituting a source of transmission of resistant and potentially pathogenic bacteria. Besides the fact that the loss of sensitivity directly influences the control of animal health, it is also reflected in public health, due to the similar treatment protocols between species (animals and humans) (SANTIAGO, 2013).

Loss of sensitivity, associated with the fact that $E$. coli was included in a WHO list as one of the main causes of diseases in different contexts (communities, hospitals or food chain) (VILA et al., 2016; LEKSHMI et al., 2017), increases the danger of spreading resistant microorganisms. Therefore, in addition to pathogenic microorganisms, the consumption of products with low hygienic-sanitary quality can transmit antimicrobial-resistant bacteria, making it difficult to treat infections (BARRETO et al., 2012).

Multidrug resistance to antimicrobials (MRA) is defined as the non-susceptibility or acquisition of resistance by a microorganism to at least one agent in three or more different antimicrobial categories (RIBEIRO et al., 2016). The results obtained from the samples in this study show that only 5.26\% (4/76) of the colonies from raw milk and $1.47 \%(2 / 136)$ of the colonies from cheese had MRA, which is an extremely low average of multidrug resistance among the investigated 
isolates. As for the total isolates, the average MRA value was $2.83 \%$ (6/212). However, due to the presence of intermediate sensitivity in some isolates, these data may change in the near future. Additionally, resistance genes can be transferred by conjugation (plasmid or transposon), transduction (bacteriophages) or transformation (direct transfer of DNA between compatible bacteria) (BAPTISTA, 2013).

Regarding the production of $\beta$-lactamase enzymes, only one isolate was suspected of producing ESBL (2be), as it showed resistance to ceftazidime and sensitivity to clavulanic acid, for which the disk approximation, MIC and TET tests were performed, as mentioned in the methodology. The result was negative for the three procedures, indicating that the isolate in question is not a producer of the enzyme $\beta$-lactamase ESBL (2be). Thus, the resistance shown to the tested drugs aztreonam and ceftazidime is most likely due to other resistance mechanisms, such as changes in porins or efflux pumps.

Four isolates were suspected of producing AmpC $\beta$-lactamases enzymes, as they showed resistance to cefoxitin. Although the Clinical and Laboratory Standards Institute (CLSI) does not have standardized tests for the determination of AmpC enzymes, research has shown satisfactory results. Therefore, to check for the existence of AmpC enzymes, the TET test was performed (SANTIAGO, 2013). All samples showed negative results for the production of the enzyme.

None of the isolates showed resistance to imipenem; thus, there were no suspects of carbapenemase enzyme production, so the modified Hodge test is not justified.

\section{CONCLUSIONS}

The present study demonstrated that the great majority of the samples of raw milk and cheese analyzed have low hygienic-sanitary quality due to their total and thermotolerant coliforms indices being above the standards required by the legislation. It also demonstrated that the E. coli colonies isolated from the samples showed high levels of sensitivity to the tested antimicrobials and low rates of multidrug resistance to the antimicrobials, none of them showed production of $\beta$-lactamase enzymes (ESBL, AmpC and carbapenemase) based on phenotypic tests performed. Nonetheless, despite the satisfactory results found regarding this, resistant colonies were still isolated; therefore, the foods in question can function as disseminators of resistance. In both cases (low hygienic-sanitary quality of the products and presence of resistant microorganisms), the products constitute a problem for public health because they can carry pathogenic microorganisms resistant to antimicrobials.

\section{AUTHORS' CONTRIBUTIONS}

Conceptualization: Pena, R. H. R.; Castro, B. G. Formal analysis: Pena, R. H. R.; Castro, B. G. Investigation: Pena, R. H. R.; Freitas, F. Writing - review \& editing: Pena, R. H. R.; Castro, B.G. Supervision: Castro, B.G. Funding acquisition: Pena, R. H. R.; Castro, B. G.

\section{AVAILABILITY OF DATA AND MATERIAL}

All data generated or analyzed during this study are included in this published article.

FUNDING

Fundação de Amparo à Pesquisa do Estado de Mato Grosso

Grant No. 041/2016

https://doi.org/10.13039/501100005286

Coordenação de Aperfeiçoamento de Pessoal de Nível Superior

Finance Code 001

https://doi.org/10.13039/501100002322

CONFLICTS OF INTEREST

The authors declare that they have no conflict of interest.

ETHICAL APPROVAL

Not applicable.

\section{ACKNOWLEDGEMENTS}

Not applicable. 


\section{REFERENCES}

ALENCAR, T.A.; MENDONÇA, E.C.L.; MARQUES, V.F.; MELO; D.A.; ROJAS, A.C.M.; MOTTA, C.C.; SANTIAGO, G.S.; DUBENCZUK, F.C.; MEDEIROS, P.T.C.; COELHO, S.M.O.; SOUZA, M.M.S. Features of hygienic-sanitary conditions at dairy units in the municipalities from the state of Rio de Janeiro, Brazil and bacteriological analysis involved in the mastitis etiology. Brazilian Journal of Veterinary Medicine, Seropédica, v.36, n.2, p.199-208, 2014. Available from: http://rbmv.org/index.php/BJVM/article/view/487. Access on: 31 Jan. 2019.

BAPTISTA, M.G.F.M. Mecanismos de resistência aos antibióticos. 2013. Dissertation (Integrated Master in Pharmaceutical Sciences) Universidade Lusófona de Humanidades e Tecnologia, Lisboa, 2013. Available from: http://www.educadores.diaadia.pr.gov.br/arquivos/ File/julho2013/biologia_artigos/mecanismos_de_resistencia_aos_antibioticos_mariagalvaoba.pdf. Access on: 19 Mar. 2019.

BARRETO, N.S.E.; SANTOS, G.C.F.; CREPALDI, A.L.; SANTOS, R.A.R. Microbiological quality and antimicrobial susceptibility of informally traded milk in Cruz das Almas county, Bahia. Semina: Ciências Agrárias, Londrina, v.33, n.6, p.2315-2326, 2012. https://doi. org/10.5433/1679-0359.2012v33n6p2315

BRAZIL. Decreto $n^{\circ}$ 9.013, de 29 de março de 2017. Regulamenta a Lei no 1.283, de 18 de dezembro de 1950, e a Lei $n^{\circ} 7.889$, de 23 de novembro de 1989, que dispõem sobre a inspeção industrial e sanitária de produtos de origem animal. Brasília: Diário Oficial da União, 2017. Available from: https://www2.camara.leg.br/legin/fed/decret/2017/decreto-9013-29-marco-2017-784536-publicacaooriginal152253-pe.html. Access on: 16 jun. 2018.

BRAZIL. Ministério da Agricultura, Pecuária e Abastecimento. Instrução Normativa $n^{\circ}$ 62, de 29 de abril de 2011. Regulamento técnico de produção, identidade e qualidade de leite tipo A, o regulamento técnico de identidade e qualidade do leite cru refrigerado, o regulamento técnico de identidade e qualidade de leite pasteurizado e o regulamento técnico da coleta de leite cru refrigerado e seu transporte a granel. Brasília: Diário Oficial da União, 2011. Available from: http://sistemasweb.agricultura.gov.br/sislegis/action/detalhaAto.do?method=co nsultarLegislacaoFederal. Access on: 23 mar. 2019.

BRAZIL. Ministério da Agricultura, Pecuária e Abastecimento. Portaria $n^{\circ}$ 146, de 07 de março de 1996. Aprovar os regulamentos técnicos de identidade e qualidade dos produtos lácteos. Brasília: Diário Oficial da União, 1996. Available from: http://sistemasweb.agricultura. gov.br/sislegis/action/detalhaAto.do?method=consultarLegislacaoFederal. Access on: 20 Jul. 2018.

BRAZIL. Ministério da Saúde, Agência Nacional de Vigilância Sanitária. Resolução-RDC $n^{\circ} 12$, de 02 de janeiro de 2001. Art. $1^{\circ}$ Aprovar o REGULAMENTO TIÉCCON SOBRE PADRÕES MICROBIOLOGICOS PARA ALIMENTOS. Brasília: Diário Oficial da União, 2001. Available from: http://bvsms.saude.gov.br/bvs/saudelegis/anvisa/2001/res0012_02_01_2001.html. Access on: 20 Jul. 2018.

CLINICAL AND LABORATORY STANDARDS INSTITUTE (CLSI). M100: Performance standards for antimicrobial susceptibility testing. Wayne: CLSI, 2017. Available from: http://file.qums.ac.ir/repository/mmrc/clsi\%202017.pdf. Access on: 30 May. 2018.

CLINICAL AND LABORATORY STANDARDS INSTITUTE (CLSI). VET08: Performance standards for antimicrobial disk and dilution susceptibility tests for bacteria isolated from animals. Wayne: CLSI, 2018.

FORSYTHE, S.J. Microbiologia da segurança dos alimentos. Porto Alegre: Artmed, 2013.

LEKSHMI, M.; AMMINI, P.; KUMAR, S.; VARELA, M.F. The food production environment and the development of antimicrobial resistance in human pathogens of animal origin. Microorganisms, Basel, v.5, n.1, p.11, 2017. https://doi.org/10.3390/microorganisms5010011

LUCEY, J.A. Raw milk consumption: risks and benefits. Nutrition Today, Boston, v.50, n.4, p.189-193, 2015. https://doi.org/10.1097/ NT.0000000000000108

LUZ, D.F.; BICALHO, F.A.; OLIVEIRA, M.V.M.; SIMÕES, A.R.P. Avaliação microbiológica em leite pasteurizado e cru refrigerado de produtores da região do Alto Pantanal Sul-Mato-Grossense. Revista Agrarian, Dourados, v.4, n.14, p.367-374, 2011. Available from: https://ojs.ufgd.edu.br/index.php/agrarian/article/view/1232. Access on: 28 ago. 2018.

RIBEIRO, L.F.; BARBOSA, M.M.C.; PINTO, F.R.; MALUTA, R.P.; OLIVEIRA, M.C.; SOUZA, V.; MEDEIROS, M.I.M.; BORGES, L.A.; AMARAL, L.A.; FAIRBROTHER, J. Antimicrobial resistance and virulence factors of Escherichia coli in cheese made from unpasteurized milk in three cities in Brazil. Foodborne Pathogens and Disease, New Rochelle, v.13, n.9, p.469-476, 2016. https://doi.org/10.1089/fpd.2015.2106 
RIBEIRO, M.C. Microbiologia prática: aplicações de aprendizagem de microbiologia básica. São Paulo: Atheneu, 2011.

ROUSHAM, E.K.; UNICOMB, L.; ISLAM, M.A. Human, animal and environmental contributors to antibiotic resistance in low-resource settings: integrating behavioural, epidemiological and One Health approaches. Proceedings of the Royal Society B, London, v.285, n.1876, p.20180332, 2018. https://doi.org/10.1098/rspb.2018.0332

SANTIAGO, G.S. Caracterização da resistência antimicrobiana e estudo fenogenotípico da produção de betalactamases em enterobactérias associadas à etiologia da mastite bovina. 2013. Dissertation (Master of Science) - Universidade Federal Rural do Rio de Janeiro, Seropédica, 2013. Available from: https://sucupira.capes.gov.br/sucupira/public/consultas/coleta/trabalhoConclusao/viewTrabalhoConclusao. jsf?popup=true\&id_trabalho=86306. Access on: 30 Jul. 2018.

SILVA, N.; JUNQUEIRA, V.C.A.; SILVEIRA, N.F.A.; TANIWAKI, M.H.; SANTOS, R.F.S.; GOMES, R.A.R. Manual de métodos de análise microbiológica de alimentos e água. São Paulo: Varela, 2010.

VILA, J.; SÁEZ-LÓPEZ, E.; JOHNSON, J.R.; RÖMLING, U.; DOBRINDT, U.; CANTÓN, R.; GISKE, C.G.; NAAS, T.; CARATTOLI, A.; MARTÍNEZ-MEDINA, M.; BOSCH, J.; RETAMAR, P.; RODRÍGUEZ-BAÑO, J.; BAQUERO, F.; SOTO, S.M. Escherichia coli: an old friend with new tidings. FEMS Microbiology Reviews, Oxford, v.40, n.4, p.437-463, 2016. https://doi.org/10.1093/femsre/fuw005

WORLD HEALTH ORGANIZATION (WHO). Antimicrobial resistance. Geneva: WHO, 2018a. Available from: http://www.who.int/en/ news-room/fact-sheets/detail/antimicrobial-resistance. Access on: 28 May 2018.

WORLD HEALTH ORGANIZATION (WHO). Antimicrobial resistance in the food chain. Geneva: WHO, 2017a. Available from: https:// www.who.int/foodsafety/areas_work/antimicrobial-resistance/amrfoodchain/en/. Access on: 21 Jan. 2019.

WORLD HEALTH ORGANIZATION (WHO). E. coli. Geneva: WHO, 2018b. Available from: http://www.who.int/news-room/fact-sheets/ detail/e-coli. Access on: 6 Aug. 2018.

WORLD HEALTH ORGANIZATION (WHO). Food safety. Geneva: WHO, 2017b. Available from: http://www.who.int/en/news-room/ fact-sheets/detail/food-safety. Access on: 14 May 2018.

WORLD HEALTH ORGANIZATION (WHO). 10 facts on food safety. Geneva: WHO, 2016. Available from: http://www.who.int/features/ factfiles/food_safety/en/. Access on: 2 Mar. 2018.

WORLD ORGANISATION FOR ANIMAL HEALTH (OIE). OIE Annual report on antimicrobial agents intended for use in animals: Better Understanding of the Global Situation. OIE: Paris, 2018. Available from: http://www.oie.int/fileadmin/Home/eng/Our_scientific_expertise/ docs/pdf/AMR/Annual_Report_AMR_3.pdf. Access on: 30 Mar. 2019.

WORLD ORGANISATION FOR ANIMAL HEALTH (OIE). One health. OIE: Paris, 2019. Available from: http://www.oie.int/en/ for-the-media/onehealth/. Access on: 30 Mar. 2019. 